\title{
Spatial Distribution and Temporal Development of Fusarium Crown and Root Rot of Tomato and Pathogen Dissemination in Field Soil
}

\author{
Yael Rekah, D. Shtienberg, and J. Katan
}

\begin{abstract}
First and third authors: Department of Plant Pathology and Microbiology, The Hebrew University of Jerusalem, Faculty of Agricultural, Food and Environmental Quality Sciences, Rehovot 76100; and second author: Department of Plant Pathology, ARO, The Volcani Center, Bet Dagan 50250, Israel.
\end{abstract}

Accepted for publication 26 May 1999.

\begin{abstract}
Rekah, Y., Shtienberg, D., and Katan, J. 1999. Spatial distribution and temporal development of Fusarium crown and root rot of tomato and pathogen dissemination in field soil. Phytopathology 89:831-839.

The spatial distribution and temporal development of tomato crown and root rot, caused by Fusarium oxysporum f. sp. radicis-lycopersici, were studied in naturally infested fields in 1996 and 1997. Disease progression fit a logistic model better than a monomolecular one. Geostatistical analyses and semivariogram calculations revealed that the disease spreads from

found to spread from one plant to the next via infection of the roots. The pathogen spread to up to four plants $(2.0 \mathrm{~m})$ on either side of the inoculated focus plant. Root colonization by the nit mutant showed a decreasing gradient from the site of inoculation to both sides of the inoculated plant. Simulation experiments in the greenhouse further established that this soilborne pathogen can spread from root to root during the growing season. These findings suggest a polycyclic nature of $F$. oxysporum $\mathrm{f}$. sp. radicis-lycopersici, a deviation from the monocyclic nature of many nonzoosporic soilborne pathogens.
\end{abstract} infected plants to a distance of 1.1 to $4.4 \mathrm{~m}$ during the growing season. By using a chlorate-resistant nitrate nonutilizing (nit) mutant of $F$. oxysporum f. sp. radicis-lycopersici as a "tagged" inoculum, the pathogen was
Additional keyword: variogram.
Fusarium crown and root rot of tomato, caused by Fusarium oxysporum Schlechtend.:Fr. f. sp. radicis-lycopersici W.R. Jarvis \& Shoemaker, is a severe disease worldwide. It is characterized by wilt at fruit ripening, cortical rot at the soil level, vascular discoloration of the lower stem, and conspicuous pinkish masses of conidia along the stem (17). In Israel, the disease is common in both greenhouses and open fields and is particularly prevalent in the Arava region in the south.

Polycyclic diseases involve pathogens that complete more than one disease cycle within a growing season; diseased plants serve as the inoculum source and support secondary infections. Logistic models are usually used to describe disease progress curves of polycyclic diseases $(4,9,34)$. Monocyclic diseases involve pathogens that complete only one disease cycle within a growing season. The inoculum that survives from the previous season serves as a primary inoculum for the next. Monomolecular models are usually used to describe disease progression curves of monocyclic diseases $(4,9)$. The notion that epidemics induced by airborne pathogens are polycyclic and those induced by soilborne pathogens are monocyclic is widely accepted, although exceptions have been noted $(5,25)$. For example, zoosporic pathogens such as Phytophthora capsici $(1,22,27)$ and Pythium spp. $(1,3,27,31)$ and nonzoosporic fungi such as Rhizoctonia solani (8), Sclerotium cepivorum (29), S. rolfsii (30), and Sclerotinia sclerotiorum (14) may complete more than one disease cycle within a growing season, thereby infecting new plants within the same season. Early studies on Fusarium crown and root rot of tomato suggested that, at early stages of the epidemic, diseased plants are distributed randomly

Corresponding author: Y. Rekah; E-mail address: rekah@agri.huji.ac.il

Publication no. P-1999-0714-01R

(C) 1999 The American Phytopathological Society within the greenhouse and that dissemination tends to occur along rows via plant-to-plant spread (17), which may indicate that the pathogen is polycyclic. Combined statistical and biological tools are now available to examine such observations. Knowledge regarding the capacity of a soilborne pathogen to spread under natural conditions from diseased to neighboring plants during the growing season is essential for the development of effective disease management programs.

Statistical methods that quantitatively define the spatial distribution of a disease may assist in determining the biological mechanisms associated with the spatial patterns $(6,7,22)$. Geostatistics can be used to quantify the degree and range of the spatial dependence of variables $(7,16,18)$ and has been used in plant pathology to quantitatively characterize changes in the spatial patterns of disease over time $(6,22,32)$. Spatial variability is measured by determining the average of the squared difference in values between pairs of samples separated by a given distance. A curve representing changes in the values of the semivariance over a distance is called a semivariogram, a measure of spatial dependency and variability. If the semivariance depends only on the distance vector $(h)$ and not on its direction, then the semivariogram is considered isotropic $(16,18)$. The anisotropic model is more appropriate in cases in which directional effects are likely to be dominant. The shape of the semivariogram may take on several different forms. For example, when records are spatially dependent, the semivariogram exhibits a saturation curve; the value of the semivariance increases with increasing distance between sample locations until it approaches a constant value (sill) at a given separation distance of spatial dependence (the range, $a$ ). Samples separated by a distance less than the range are spatially related, but those that are located at a larger distance from each other are spatially independent $(6,7,16,18)$. Alternatively, when records are spatially independent, values of the semivariance do not change with distance and the semivariogram approximates a straight line. It is possible to analyze disease in- 
cidence data (describing either diseased or healthy individual plants) (32), or disease severity values (reflecting the magnitude of the infection) (22).

Chlorate-resistant nitrate nonutilizing (nit) mutants of pathogenic forms of $F$. oxysporum can be used as markers in ecological studies, with the appropriate selection media $(13,33)$. It was demonstrated (13) that such nit mutants are not inferior to the wild type in traits such as pathogenicity, growth, and survival in soil. These nit mutants can easily be reisolated from infected plants and infested soil and distinguished from the wild-type strain; therefore, such "tagged" inocula can be used as a tool for epidemiological studies.

In this project, we studied the progress of crown and root rot disease of tomato in time and space under field conditions and ex- plored the possibility of a diseased plant becoming a source of infection for other plants during the same growing season. Geostatistical analysis was used to quantify the spatial spread of disease over time in naturally infested soils. Selected nit mutants were used as a tagged pathogen in some of the experiments. A preliminary report on this study has been published (26).

\section{MATERIALS AND METHODS}

Media. Liquid Czapek medium contained, per liter, $1 \mathrm{~g}$ of $\mathrm{K}_{2} \mathrm{HPO}_{4}, 2 \mathrm{~g}$ of $\mathrm{NaNO}_{3}, 0.5 \mathrm{~g}$ of $\mathrm{KCl}, 0.5 \mathrm{~g}$ of $\mathrm{MgSO}_{4} \cdot 7 \mathrm{H}_{2} \mathrm{O}, 0.01 \mathrm{~g}$ of $\mathrm{FeSO}_{4}, 30 \mathrm{~g}$ of sucrose, and $0.25 \mathrm{~g}$ of chloramphenicol. Yeast extract liquid medium contained, per liter, $5 \mathrm{~g}$ of peptone, $5 \mathrm{~g}$ of
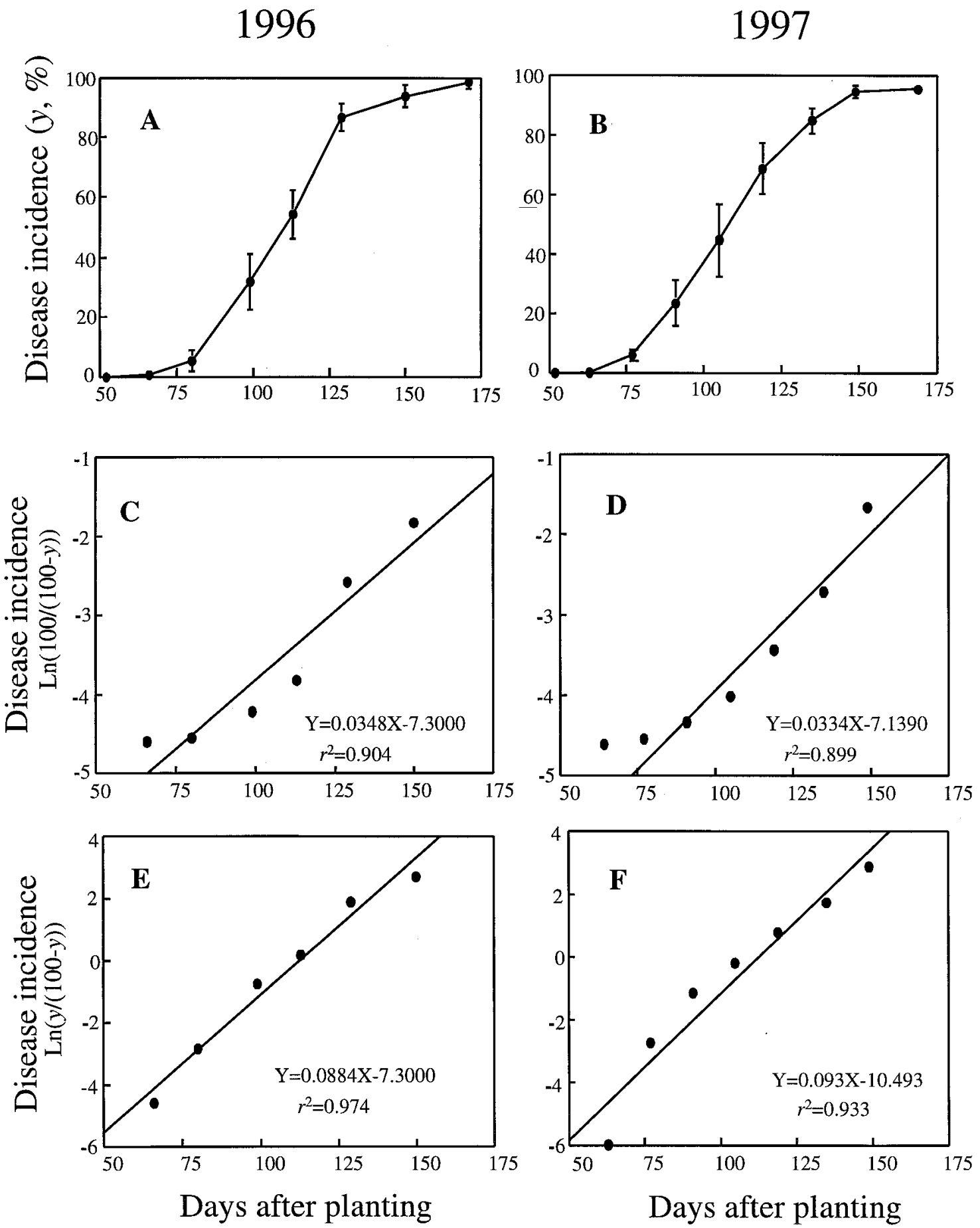

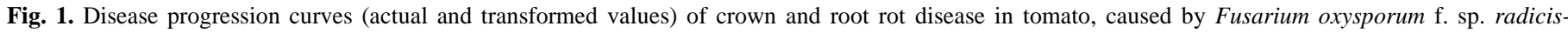

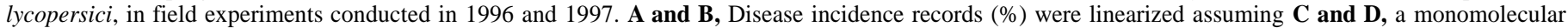
model $(\ln [100 /(100-y)])$ or $\mathbf{E}$ and $\mathbf{F}$, a logistic model $(\ln [y /(100-y)])$. Vertical bars represent standard error. 
yeast extract, and $20 \mathrm{~g}$ of glucose. Both media were used to grow the pathogen.

The Fusarium minimal medium (FMM) was Puhalla's MM (20), a sucrose-salt medium containing nitrate as the nitrogen source and containing, per liter, $30 \mathrm{~g}$ of sucrose, $2 \mathrm{~g}$ of $\mathrm{NaNO}_{3}, 1 \mathrm{~g}$ of $\mathrm{KH}_{2} \mathrm{PO}_{4}, 0.5 \mathrm{~g}$ of $\mathrm{MgSO}_{4} \cdot 7 \mathrm{H}_{2} \mathrm{O}, 0.5 \mathrm{~g}$ of $\mathrm{KCl}, 0.2 \mathrm{ml}$ of a trace elements solution, and $20 \mathrm{~g}$ of Difco agar (Difco Laboratories, Detroit). The trace elements solution contained, per $95 \mathrm{ml}$ of distilled water, $5 \mathrm{~g}$ of citric acid, $5 \mathrm{~g}$ of $\mathrm{ZnSO}_{4} \cdot 7 \mathrm{H}_{2} \mathrm{O}, 4.75 \mathrm{~g}$ of $\mathrm{FeSO}_{4}$, $1 \mathrm{~g}$ of $\mathrm{Fe}\left(\mathrm{NH}_{4}\right)_{2}\left(\mathrm{SO}_{4}\right)_{2} \cdot 6 \mathrm{H}_{2} \mathrm{O}, 250 \mathrm{mg}$ of $\mathrm{CuSO}_{4} \cdot 5 \mathrm{H}_{2} \mathrm{O}, 50 \mathrm{mg}$ of $\mathrm{MnSO}_{4} \cdot \mathrm{H}_{2} \mathrm{O}, 50 \mathrm{mg}$ of $\mathrm{H}_{3} \mathrm{BO}_{3}$, and $50 \mathrm{mg}$ of $\mathrm{Na}_{2} \mathrm{MoO}_{4} \cdot 2 \mathrm{H}_{2} \mathrm{O}$. FMM was used for vegetative compatibility group (VCG) determination of the nit mutant. Another medium was based on FMM amended with $15 \mathrm{~g}$ of $\mathrm{KClO}_{3}$ per liter and $1.6 \mathrm{~g}$ of $\mathrm{L}$-asparagine per liter, acidified with $1.6 \mathrm{ml}$ of $90 \%$ lactic acid per liter (FMMCPA) to suppress bacterial contamination. FMMCPA was used as a selective medium for recovering and enumerating chlorate-resistant nit mutants.

Temporal and spatial disease progression in a natural epidemic. The development of Fusarium crown and root rot of tomato was studied in the Kikar Sedom Experimental Station located at En Tamar, close to the Dead Sea, in the southeastern part of Israel. The plots were naturally infested with $F$. oxysporum f. sp. radicis-lycopersici. Tomato (Lycopersicon esculentum Miller cv. 5656) transplants, susceptible to the disease, were planted in the first week of October in 1995 and 1996, for the corresponding 1996 and 1997 growing seasons. Four experimental plots were designated in the 1996 season and eight plots in 1997. Each plot consisted of six 11-m-long rows; the distance between rows was $1.93 \mathrm{~m}$ and plants were spaced $0.5 \mathrm{~m}$ apart. Row direction was

\section{6}

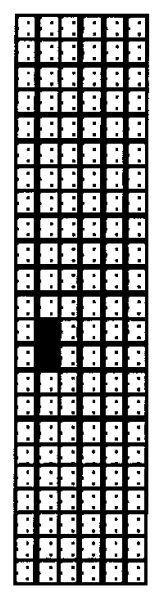

66

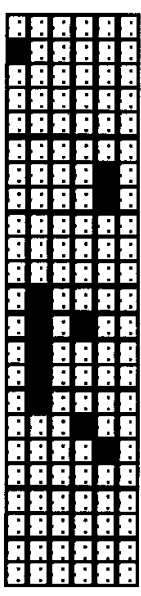

80

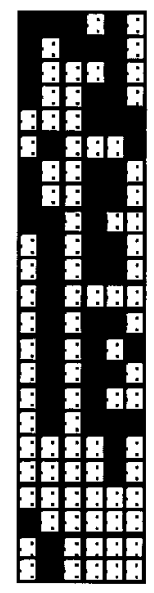

99

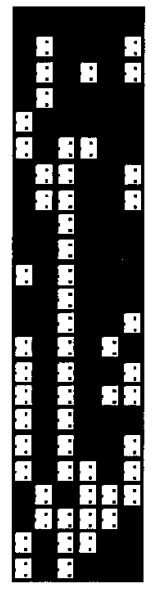

113

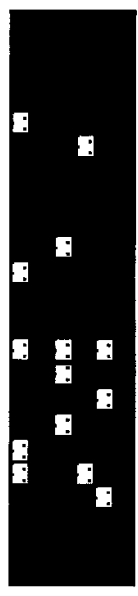

129

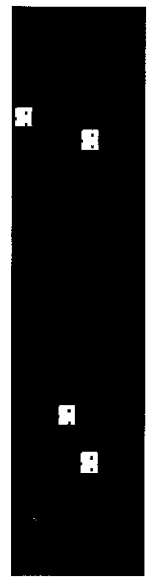

150

\section{Days after planting}

\section{7}

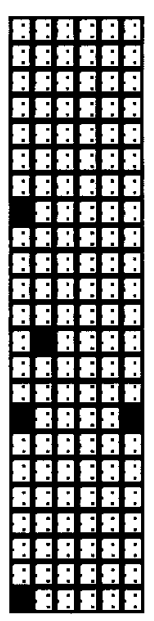

77

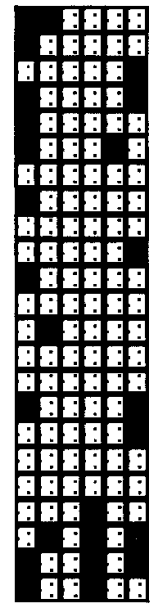

91

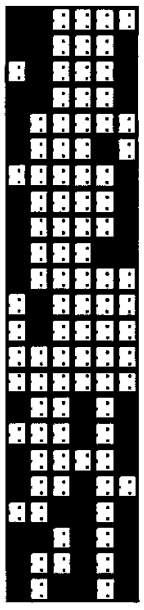

105

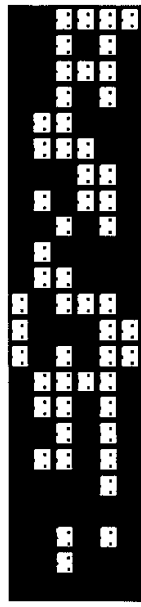

119

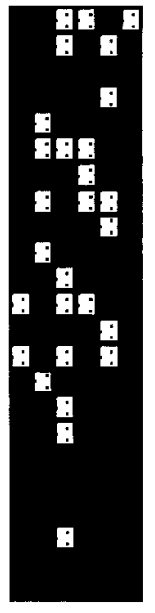

135

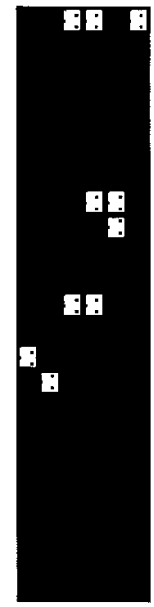

149

\section{Days after planting}

Fig. 2. Spatial and temporal progress of crown and root rot of tomato, caused by Fusarium oxysporum f. sp. radicis-lycopersici, in experimental plots in 1996 and 1997. Each square represents an individual plant that is either diseased (black squares) or healthy (white dotted squares). Plots consisted of six rows, $1.93 \mathrm{~m}$ apart; there were 22 or 23 plants in each row, grown $0.5 \mathrm{~m}$ apart. Results are given for plot 1 in 1996 and plot 1 in 1997. 
north to south. The plots were prepared, cultivated, and treated with pesticides according to the recommendations of the Extension Service for that region. Irrigation was applied via a drip system. Two (in 1996) and four (in 1997) plots were fumigated prior to planting with methyl bromide at a rate of $70 \mathrm{~g} / \mathrm{m}^{2}$ according to the local practice of tomato cultivation in this area. Fumigated plots were used for studies with the nit mutant, as described below. The nonfumigated plots were used for monitoring the temporal progress and the spatial distribution of the disease. Disease incidence was assessed at 14-day intervals, eight times in 1996 and nine times in 1997. Assessments were initiated shortly after disease onset and continued until 170 days after planting. Plants were considered diseased when they exhibited typical irreversible wilt symptoms accompanied with brown necrosis on the crown and vascular discoloration in the lower stem. Plants that were considered diseased were tagged with a colored plastic band at each assessment and their exact location in the plot was recorded. The identity of the pathogen was verified by isolation from randomly chosen diseased plants on a selective peptone pentachloronitrobenzene medium and inoculating tomato seedlings as described previously (20).

Geostatistical analysis. We used geostatistics to quantify the temporal development and spatial distribution of crown and root rot epidemics. Using disease incidence records as the tested vari-
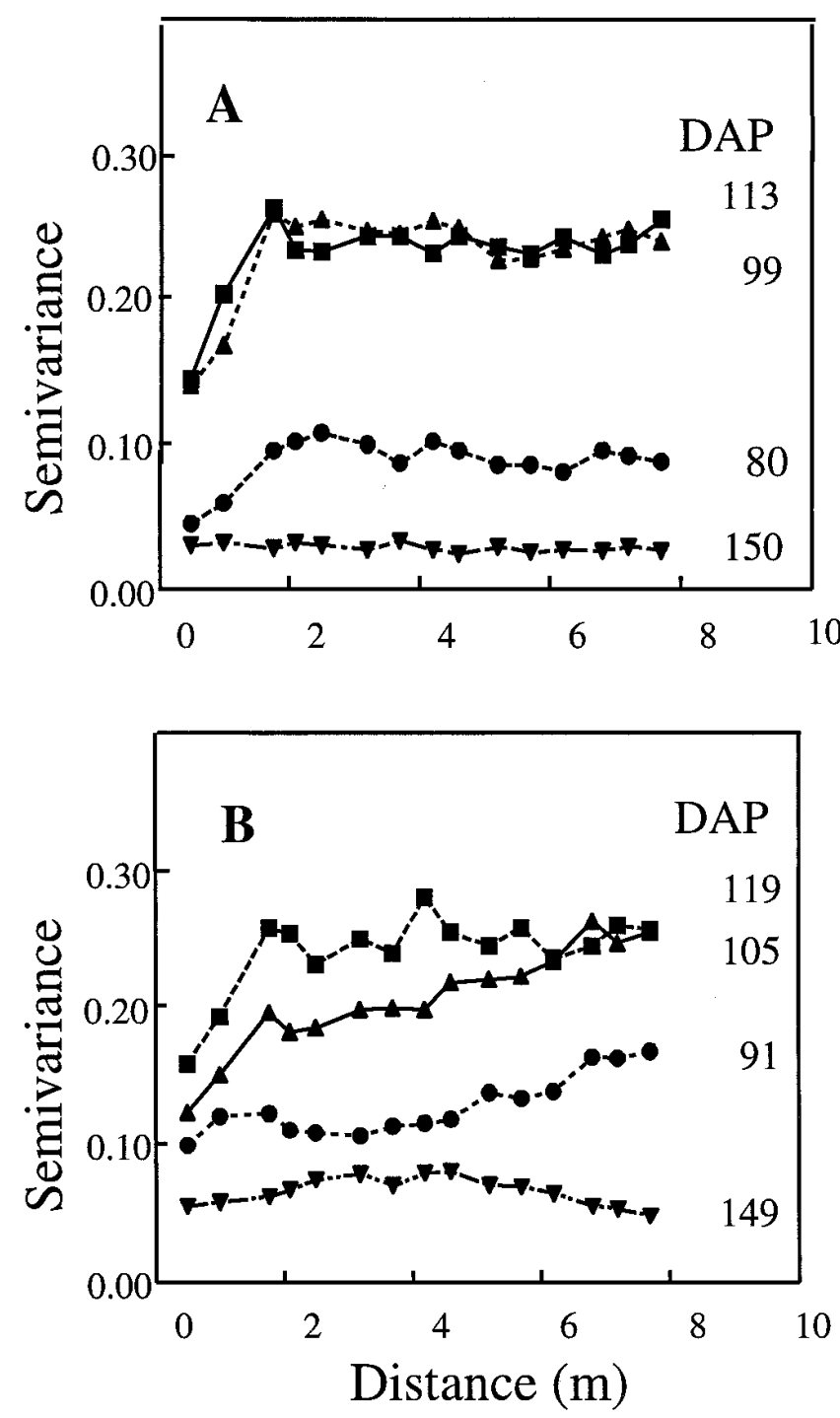

Fig. 3. The spatial semivariograms for crown and root rot disease of tomato, caused by Fusarium oxysporum f. sp. radicis-lycopersici, in A, 1996 and B, 1997 field experiments. Analyses were performed for various dates, expressed as days after planting (DAP). Results are given for plot 1 in 1996 and plot 1 in 1997. able, a value of 0 denoted a healthy plant and a value of 1 a diseased plant. Analyses were performed separately for each experimental plot and for each of the disease assessments. Examination of plant rooting systems revealed that the roots did not cross the intermediate dry area between the drip-irrigated rows and were concentrated only along the rows. Consequently, within-row distribution of the disease was assumed and an anisotropic model was employed. GS+ software (version 2.3; Gamma Design Software, Plainwell, MI) was used for the geostatistical analyses.

Use of nit mutant inoculum for assessing disease spread. The spread of the pathogen from diseased to neighboring plants was studied in the fumigated plots using tagged inoculum (nit mutants of the pathogen). Spontaneous nit mutants of pathogenic F. oxysporum were recognized and distinguished from the wild type by plating on FMM and FMMCPA media (13). The nit mutant colony on FMM was thin, while the wild-type colony exhibited a dense growth. On FMMCPA medium, the nit mutant colony grows normally, but the wild-type pathogen cannot grow due to the presence of chlorate. Two nit mutants, originating from pathogenic isolates of $F$. oxysporum f. sp. radicis-lycopersici; FORL II-D (VCG 0090II) and FORL C-544 (VCG 0091I) (20), obtained from T. Katan at ARO, the Volcani Center, Israel, were used.

Inoculum was prepared as follows: a disk of the nit mutant grown on FMMCPA medium was incubated in $5 \mathrm{ml}$ of yeast extract at $27^{\circ} \mathrm{C}$ for $24 \mathrm{~h}$. The disk and $1 \mathrm{ml}$ of the yeast extract were then transferred to $100 \mathrm{ml}$ of Czapek liquid medium in 250-ml flasks in a reciprocal shaker ( 88 strokes per min) and incubated at $27^{\circ} \mathrm{C}$ for 5 days. The suspension was filtered through eight cheesecloth layers and centrifuged (Sorvall RC5C-plus super speed, rotor SLA-1500; Sorvall Instruments, Newtown, CT) for $15 \mathrm{~min}$ at $4^{\circ} \mathrm{C}$ and 7,400 $\times g$. The pellet was suspended in water and mixed with a sandy soil to obtain a final concentration of $2 \times 10^{6} \mathrm{CFU} / \mathrm{g}$ of soil at $10 \%$ moisture. The infested soil was incubated for 80 days at $27^{\circ} \mathrm{C}$, after which only chlamydospores were detected in the soil. At that stage, the inoculum density was 1 to $5 \times 10^{4} \mathrm{CFU} / \mathrm{g}$ of soil. Samples $(4 \mathrm{~g})$ of the nit mutant-infested soil were placed in small bags made of nylon netting. On planting day, bags with infested soil were placed near the roots at a depth of $8 \mathrm{~cm}$. In each experimental plot, 6 (in 1996) or 12 (in 1997) plants were randomly chosen and marked with small colored flags. Half of the plants were inoculated with one nit mutant strain and the other half with the other strain. Differences between the two strains with respect to the parameters used were insignificant; therefore, results for the two strains were pooled.

Plants inoculated with the nit mutant were considered to be a potential source (focus) from which the pathogen could spread to neighboring plants. Pathogen spread was determined by recording diseased plants near the nit mutant-inoculated focus plants. Samples taken from the roots and lower stem parts of these diseased plants were plated on FMMCPA medium to confirm that disease has been induced by the nit mutant. The identity of the nit mutant was further verified by VCG testing (20).

The rate at which $F$. oxysporum. f. sp. radicis-lycopersici spread from one plant to another was determined for each of the inoculated focus plants by means of regression analysis. The dependent variable in the analysis was the distance of the newly diseased plants from the inoculated focus plant, and the independent variable was the time (days after inoculation) of infection. The slope of the regression equation was a measure for the rate of disease spread. Frequency distribution of the slope rates was calculated to estimate the mean and variance of the rate at which the disease had spread from the inoculated plants.

The growth rate of the pathogen on detached roots under controlled conditions was assessed in artificial-inoculated experiments. Detached roots of 4-month-old tomato plants (cv. 5656; $n=75$ ) were inoculated by putting a disk of the nit mutant on Czapek medium amended with peptone $(6 \mathrm{~g} / \mathrm{liter})$ on the upper part of the root and incubated at $27^{\circ} \mathrm{C}$ in closed, moist plastic bags. Sections of the roots were periodically removed and plated on FMMCPA 
selective medium. The rate of pathogen spread was calculated. The mutant was also grown on Czapek medium amended with peptone, incubated at $27^{\circ} \mathrm{C}$, and the growth rate assessed.

Roots colonization by nit mutants. Root colonization by the nit mutant was used to assess the ability of the pathogen to spread spatially from root to root in the field. The plants were grown in a sandy soil in a rainless region and were drip-irrigated; therefore, most of the roots were located within rows in the upper soil layer (mostly 10 to $15 \mathrm{~cm}$ in depth). This made it possible to uncover and detach most of the rooting system. Root systems of diseased plants artificially inoculated with nit mutant and roots of two to three adjacent plants were carefully unearthed. Roots were tagged and their position and location marked. Roots were then cut into 5 -cm segments, and the specific location of each segment relative to the inoculated focus plant was recorded. Each segment was cut into 25 subpieces (each $2 \mathrm{~mm}$ long) that were plated on FMMCPA medium to verify the presence of the nit mutant. Plates were incubated for 5 days at $27^{\circ} \mathrm{C}$, and colonization with the nit mutant of the pathogen was determined. The percentage of root subpieces colonized by the pathogen was calculated and served as a measure of the spatial spread of the pathogen along the roots. This procedure was repeated four times during the 1997 growing season.

Greenhouse experiments for assessing root-to-root spread. A nit mutant was used in simulation experiments in the greenhouse to verify conclusions derived from studies carried out in the field. Two tomato plants (cv. 5656) were planted $40 \mathrm{~cm}$ apart in plastic containers $(58 \times 18 \times 17 \mathrm{~cm}$; length, width, and height, respectively) filled with methyl bromide-fumigated soil. The plants were dripirrigated three times daily by two drips of 2 liters $/ \mathrm{h}$. A nit mutant of the pathogen was placed, as in the field experiments, near the roots of one of the two plants, the focus plant. Some of the containers were divided by a $2.5-\mathrm{cm}$-wide wooden barrier. There was an opening of $10 \times 10 \mathrm{~cm}$ in the center of each barrier. The openings were sealed with a 50- $\mu \mathrm{m}$-mesh nylon net (Sinun Products, Petach Tikva, Israel) and the space between the nets was filled with noninfested, fumigated soil. This frame was used to prevent contact between the root systems of the plants grown on either side of the barrier without preventing possible pathogen movement through the net. The contact area between the wooden barrier and the plastic container walls was sealed with R.T.V. silicone glue (Soudal N.V., Turnhout, Belgium) to avoid root penetration from the sides. The experiment was repeated twice. There were five containers without barriers and four containers with barriers in the first experiment and eight and five containers for the two treatments, respectively, in the second experiment. The plants' roots were examined for nit mutant colonization 70 days after planting in the first experiment and 140 days after planting in the second experiment.

At the end of each experiment, plants roots were unearthed and five segments were taken from each plant (one from the crown and four from different sites on the root system). Each segment was cut into five subpieces and plated on FMMCPA selective medium (a total of 25 samples per plant). Colonization incidence for each plant was calculated.

In additional experiments, nit mutants in nylon bags, identical to those used for plant inoculation in the field, were placed in soil without plants in each of 10 containers in order to identify possible pathogen movement in the absence of plants. Soil dilutions on FMMCPA of soil samples at distances of 2, 5, and $10 \mathrm{~cm}$ from the inoculum source were made every 21 to 25 days for 90 days. Irrigation of the containers was the same as for containers with plants. At the end of each experiment, inoculum in the nylon bags was assessed for viability. This experiment was repeated once.

\section{RESULTS}

Temporal and spatial disease progress in a natural epidemic. Progression of Fusarium crown and root rot disease in tomato plants was recorded in naturally infested plots in 1996 and
1997. The first diseased plants were observed 66 days (in 1996) and 63 days (in 1997) after planting. Disease incidence increased thereafter, and by the end of the season (approximately 170 days after planting), it had reached 97 and 93\% in 1996 and 1997, respectively (Fig. 1A and B). Disease progression curves exhibited a logistic shape in both years. An attempt to linearize the curves using the $\ln [100 /(100-y)]$ transformation, which is often used to linearize monomolecular equations, was not fully satisfactory because data points were not randomly distributed around the regression lines (Fig. 1C and D). However, a logit transformation, $\ln [y /(100-y)]$, which is often used to linearize logistic equations, resulted in adequate linearization of the curves (Fig. 1E and F).

The spatial pattern of diseased plants in the field changed over time. In the early stages of the epidemic, diseased plants were randomly scattered over the entire field plot. However, at later stages, newly diseased plants were observed more frequently adjacent to the previously diseased ones, and distinct foci of disease patches were formed in the field. Foci enlarged mainly within, rather than between, rows. Eventually, most of the plants in the plot became diseased. An example of the spatial and temporal progress of the disease in two plots is illustrated in Figure 2. Similar trends were observed in the other four plots (data not shown).

Geostatistical analyses of the spatial distribution of the disease resulted in a typical semivariogram shape over time in both years (Fig. 3). Spatial variability was low in the early stages of the epidemic, increased gradually afterwards, and became low again by the end of the season. The low spatial variability at the early stages of the epidemic ( 80 to 91 days after planting) indicates that the first diseased plants were not spatially related to the adjacent plants. Semivariograms showing typical spatial dependency with limited random variation were obtained during the middle stages of the epidemic (99 to 119 days after planting). The range values at that

TABLE 1. Incidence of crown and root rot disease in tomato induced by Fusarium oxysporum f. sp. radicis-lycopersici and semivariogram parameters for the spherical model at different dates in 1996 and 1997

\begin{tabular}{|c|c|c|c|c|c|c|}
\hline Plot & $\begin{array}{c}\text { Days after } \\
\text { planting }\end{array}$ & $\begin{array}{c}\text { Disease } \\
\text { incidence }(\%)\end{array}$ & Nugget $^{\mathrm{a}}$ & Sill $^{\mathrm{b}}$ & Range $^{c}$ & $R^{2 \mathrm{~d}}$ \\
\hline \multicolumn{7}{|l|}{1996} \\
\hline \multirow[t]{4}{*}{ Plot 1} & 80 & 8.0 & 0.017 & 0.093 & 2.18 & 0.766 \\
\hline & 99 & 38.4 & 0.072 & 0.243 & 2.09 & 0.884 \\
\hline & 113 & 60.1 & 0.076 & 0.239 & 1.73 & 0.888 \\
\hline & 149 & 96.4 & 0.001 & 0.028 & 0.01 & 0.000 \\
\hline \multirow[t]{4}{*}{ Plot 2} & 80 & 2.9 & 0.013 & 0.026 & 6.73 & 0.766 \\
\hline & 99 & 25.4 & 0.070 & 0.200 & 3.58 & 0.948 \\
\hline & 113 & 48.6 & 0.090 & 0.270 & 4.20 & 0.865 \\
\hline & 149 & 91.1 & 0.078 & 0.080 & $>8.10^{\mathrm{e}}$ & 0.025 \\
\hline \multicolumn{7}{|l|}{1997} \\
\hline \multirow[t]{4}{*}{ Plot 1} & 91 & 17.4 & 0.093 & 0.160 & $>8.10$ & 0.735 \\
\hline & 105 & 34.1 & 0.132 & 0.254 & $>8.10$ & 0.901 \\
\hline & 119 & 62.9 & 0.103 & 0.250 & 2.08 & 0.834 \\
\hline & 149 & 94.7 & 0.050 & 0.067 & 2.73 & 0.139 \\
\hline \multirow[t]{4}{*}{ Plot 2} & 77 & 7.6 & 0.027 & 0.074 & 1.01 & 0.262 \\
\hline & 91 & 27.3 & 0.090 & 0.217 & 3.30 & 0.801 \\
\hline & 119 & 81.1 & 0.089 & 0.154 & 3.42 & 0.430 \\
\hline & 135 & 91.7 & 0.081 & 0.099 & $>8.10$ & 0.458 \\
\hline \multirow[t]{4}{*}{ Plot 3} & 77 & 9.9 & 0.056 & 0.108 & 1.00 & 0.281 \\
\hline & 91 & 40.2 & 0.065 & 0.245 & 1.14 & 0.687 \\
\hline & 105 & 65.9 & 0.082 & 0.223 & 3.05 & 0.752 \\
\hline & 135 & 90.0 & 0.060 & 0.097 & 4.76 & 0.662 \\
\hline \multirow[t]{5}{*}{ Plot 4} & 91 & 9.9 & 0.021 & 0.107 & 3.29 & 0.360 \\
\hline & 105 & 20.5 & 0.069 & 0.193 & 4.10 & 0.581 \\
\hline & 119 & 50.8 & 0.112 & 0.265 & 4.39 & 0.936 \\
\hline & 135 & 75.8 & 0.110 & 0.202 & 5.22 & 0.889 \\
\hline & 149 & 90.2 & 0.051 & 0.066 & 5.16 & 0.628 \\
\hline
\end{tabular}

a Value of the semivariogram near the origin represents microdistributional and measurement error.

b The limiting value of the semivariogram for large distance, $h$.

${ }^{c}$ Range $(\mathrm{m})$ for the semivariogram defines the distance at which samples are no longer spatially related.

d Correlation of the spherical curve as fitted by GS+ software.

e Estimation of range beyond active lag distance. 
time were between 1.1 and $4.4 \mathrm{~m}$. At the end of the season, most of the plants were already diseased and, consequently, the semivariograms reflected an absence of spatial dependency. The semivariogram values calculated for six blocks are shown in Table 1.

Temporal and spatial disease spread from inoculated plants. Disease spread in the field was recorded in 1996 and 1997 in plants artificially inoculated with a nit mutant of $F$. oxysporum f. sp. radicislycopersici. By the end of the season, the nit mutant pathogen had infected and caused disease symptoms in 98 to $100 \%$ of the inoculated plants. The pathogen had spread to both sides of the inoculated plants, along the rows (Fig. 4), in a pattern similar to that observed in the naturally infested plots (Fig. 2). It was detected at a distance of up to four plants $(2 \mathrm{~m})$ from the inoculated focus plants (Table 2). Geostatistical analysis was performed for four blocks that were planted in 1997. The calculations were made for two dates (119 and 169 days after planting) when disease incidence caused by the nit mutant was about 12 and $35 \%$, respectively. The variogram function of one representative block is shown in Figure 5. The range in all of the blocks varied between 1.0 and $4.8 \mathrm{~m}$, similar to the distances calculated for the naturally infected plants (Fig. 3).

Spread of the nit mutant from the inoculated focus plants to a distance of at least one plant $(0.5 \mathrm{~m})$ was observed in 75 and $81 \%$ of the cases in 1996 and 1997, respectively (Table 2). In 25\% (1996) and 50\% (1997) of the cases, the pathogen spread to a distance of $1.0 \mathrm{~m}$ (two plants) or more. The pathogen progressed along the rows consecutively, infecting one plant after another, indicating disease spread from root to root. Typical examples of disease spread from three foci in 1996 and four foci in 1997 are presented in Figure 6. Following the first record of disease symptoms in the inoculated focus plant, disease progressed 50 to $150 \mathrm{~cm}$ within 14 to 64 days. The rate of disease spread from diseased plants was calculated for each focus and ranged from 1.0 to 3.1 (1.8 \pm 0.08 , mean \pm standard error) $\mathrm{cm}$ per day (Fig. 7). For comparison, $F$. oxysporum f. sp. radicis-lycopersici spread was also assessed on detached tomato roots. The rate of spread was 1.3 to 4.5 ( $\pm 0.43-$ $0.54) \mathrm{cm}$ per day, which resembled the calculated field rates. The rate of linear mycelial growth of the pathogen on Czapek medium supplemented with $6 \mathrm{~g}$ of peptone, carried out in a parallel experiment at $27^{\circ} \mathrm{C}$, was 0.7 to $0.9 \mathrm{~cm}$ per day.
Disease symptoms induced by the nit mutant in the field were similar to those induced by the wild-type pathogen. In addition, sporulation was observed on the stem of the nit mutant-inoculated plant as well as on plants infected by the wild-type pathogen. Isolates of the pathogen obtained from the inoculated focus plants, the adjacent diseased plants, and the conidia formed on the plants' crown were confirmed as the nit mutant of $F$. oxysporum f. sp. radicis-lycopersici. VCG tests confirmed that they were the same as the original strain.

Mode of disease spread. Colonization of $F$. oxysporum $\mathrm{f}$. sp. radicis-lycopersici along the roots of inoculated focus and adjacent infected plants was determined four times during the 1997 growing season. Results from one representative sample are shown in Figure 8. A high colonization rate of root segments (>80\%) was observed in roots of the inoculated plant at the inoculation site and up to a distance of $25 \mathrm{~cm}$ away. Root colonization decreased gradually with increasing distance from the inoculation site in both directions. Only 40 to $60 \%$ of the root segments had been colonized at a distance of $50 \mathrm{~cm}$ from the inoculation site. A similar pattern was observed for the adjacent plants; root segments were colonized at higher percentages close to the site of inoculation on the plants' roots and the percentage of colonization decreased with distance.

Simulation studies for assessing root-to-root spread. The possible spread of hte nit mutant from roots of an inoculated focus to

TABLE 2. The distance to which Fusarium oxysporum f. sp. radicis-lycopersici spreads from focus plants (inoculated with the nit mutant of the pathogen) to adjacent plants at distances of 0.5 to $2.0 \mathrm{~m}^{\mathrm{a}}$

\begin{tabular}{|c|c|c|c|c|c|c|}
\hline \multirow[b]{2}{*}{ Year } & \multirow{2}{*}{$\begin{array}{c}\text { No. of } \\
\text { inoculated plants }\end{array}$} & \multicolumn{5}{|c|}{ Distance of spread $(\mathrm{m})^{\mathrm{b}}$} \\
\hline & & $0^{c}$ & 0.5 & 1.0 & 1.5 & 2.0 \\
\hline 1996 & 12 & 25.0 & 50.0 & 16.7 & 8.3 & 0 \\
\hline 1997 & 48 & 19.1 & 30.9 & 34.0 & 13.8 & 2.2 \\
\hline
\end{tabular}

${ }^{a}$ Results are expressed as percentage of diseased plants at each indicated distance from the focus plants. In 1996 and 1997, 100 and 98\%, respectively, of the inoculated plants were diseased.

$\mathrm{b}$ The distance between two adjacent plants was $0.5 \mathrm{~m}$.

c The inoculated focus plants.

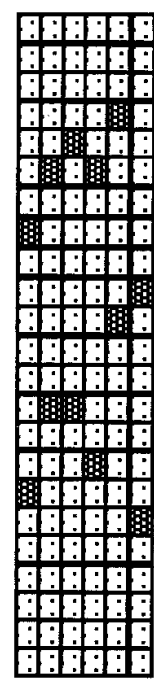

77

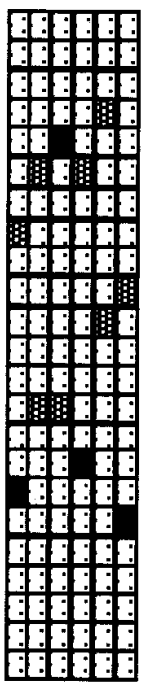

91

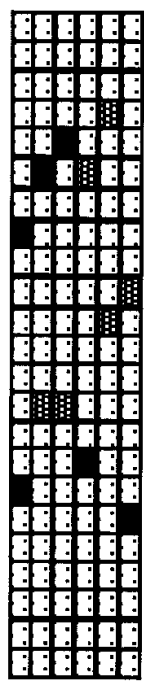

105

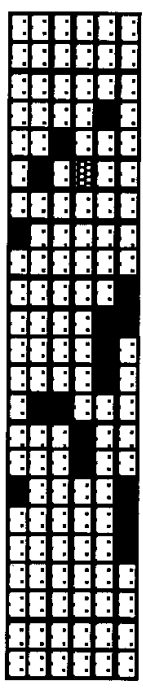

119

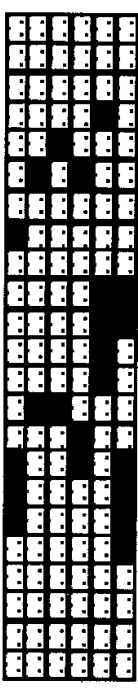

135

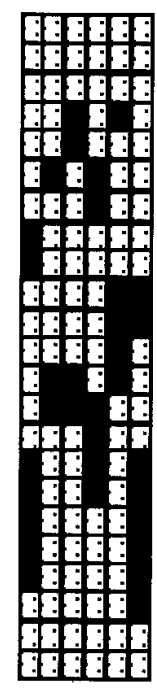

149

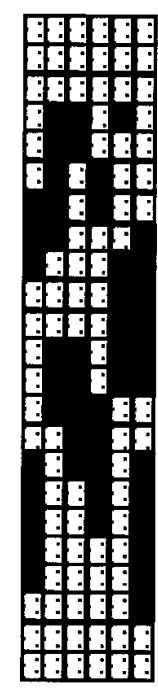

169

\section{Days after planting}

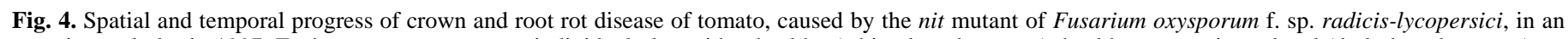

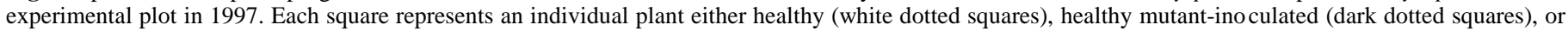
diseased (black squares). Plots consisted of six rows, $1.93 \mathrm{~m}$ apart; there were 23 plants in each row, grown $0.5 \mathrm{~m}$ apart. 


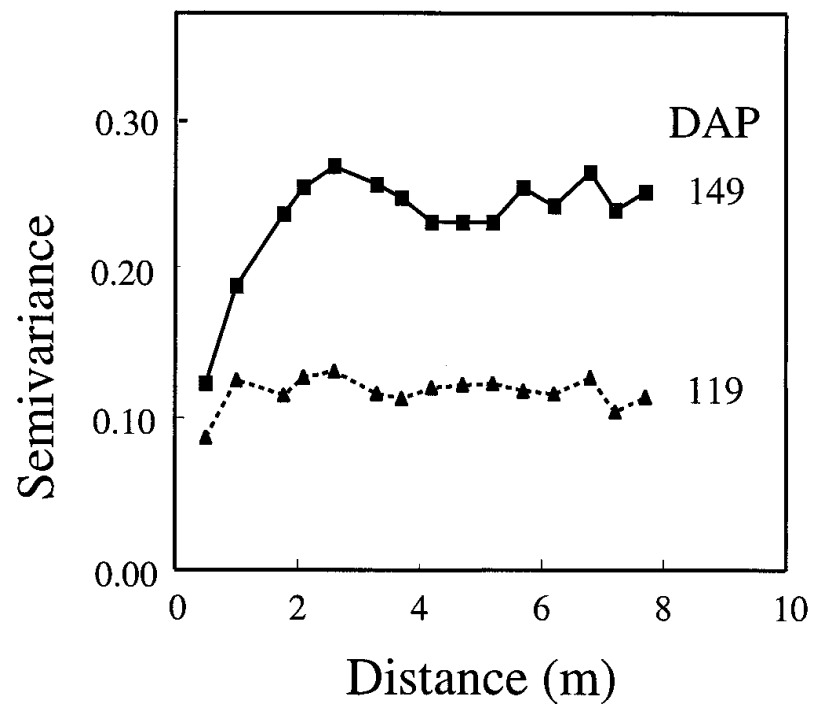

Fig. 5. The spatial semivariograms for crown and root rot disease of tomato, caused by the nit mutant of Fusarium oxysporum f. sp. radicis-lycopersici, in the 1997 field experiment. Analyses were performed for two dates, expressed as days after planting (DAP), for the plot represented in Figure 4.
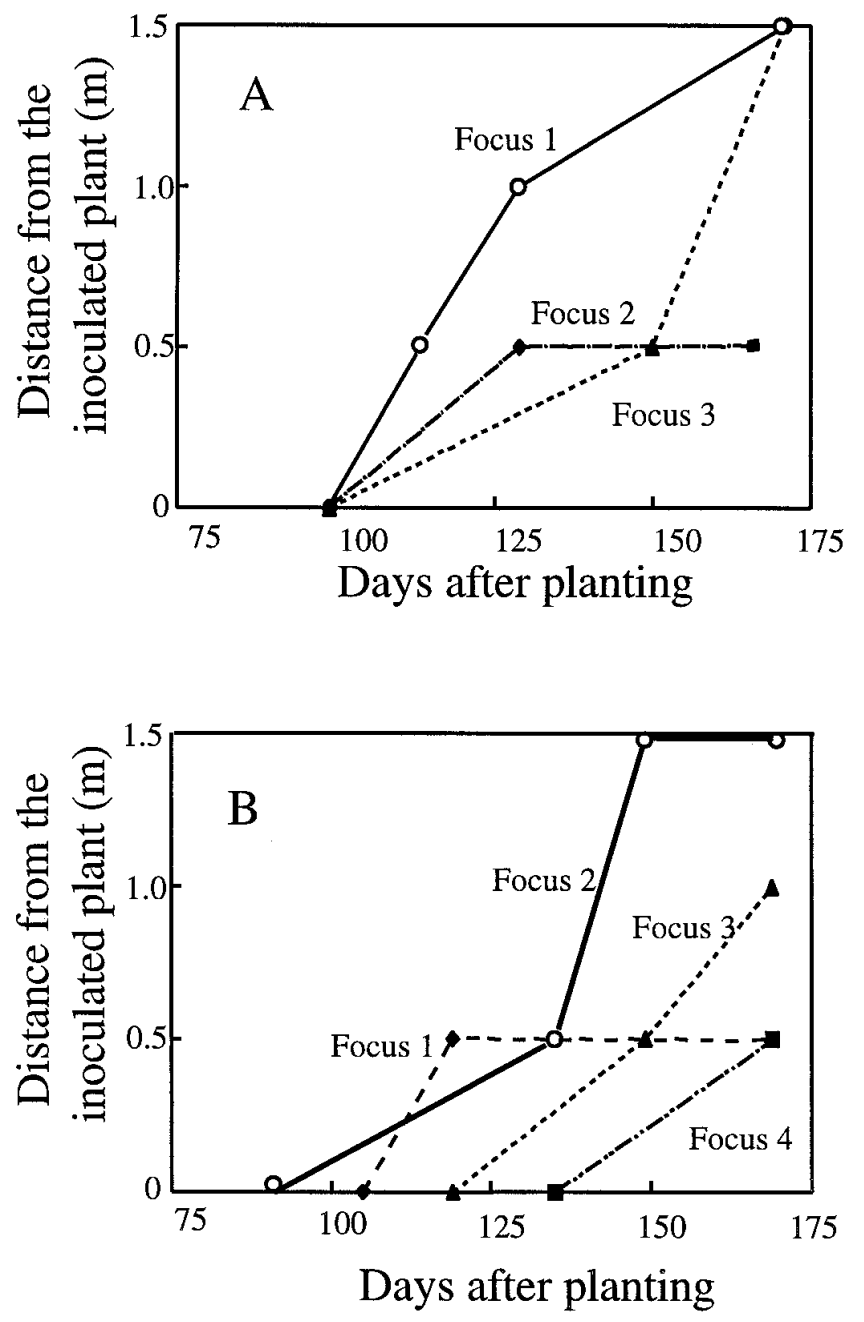

Fig. 6. Spread of nit mutants of Fusarium oxysporum f. sp. radicis-lycopersici from artificially inoculated plants to adjacent plants in A, 1996 and B, 1997. Curves are initiated at the time after planting at which the inoculated focus plant was diseased. Distance between adjacent plants is $0.5 \mathrm{~m}$. roots of adjacent plants was studied in two experiments in containers with and without barriers between the roots of the two plants. When no barriers existed, 8 out of 11 plants adjacent to the focus plants were infected, apparently via root-to-root dissemination (Table 3 ). In both experiments, plants adjacent to the focus plants were less colonized by the pathogen than were the focus plants, apparently because they became infected at a later stage, as was also observed in the field experiments (Figs. 6 and 8). In contrast, in the containers with barriers, only one plant out of nine became infected, at a very low rate (Table 3); apparently, the frame in this container was not fully sealed. In containers without plants, the pathogen did not spread in the soil. It was not detected at distances of 2, 5 , or $10 \mathrm{~cm}$ from the site of inoculation, even when samples were taken 90 days after the initiation of the experiment. The pathogen was still present at the inoculation site after 90 days $(12,000 \mathrm{CFU} / \mathrm{g}$ of soil), compared with $16,000 \mathrm{CFU} / \mathrm{g}$ of soil at the beginning of the experiment.

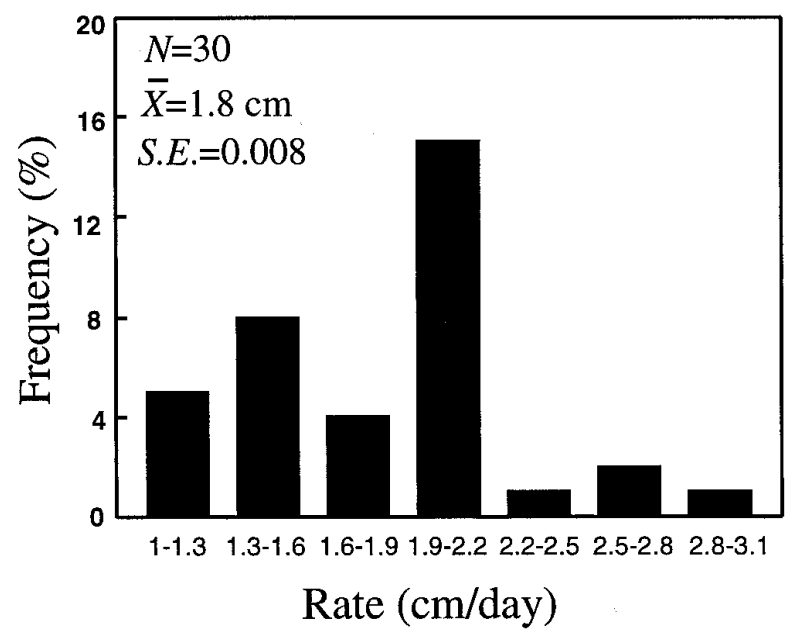

Fig. 7. Frequency distribution of the rate at which nit mutants of Fusarium oxysporum f. sp. radicis-lycopersici spread from artificially inoculated plants to adjacent plants. The analysis included 30 cases recorded in 1996 and 1997.

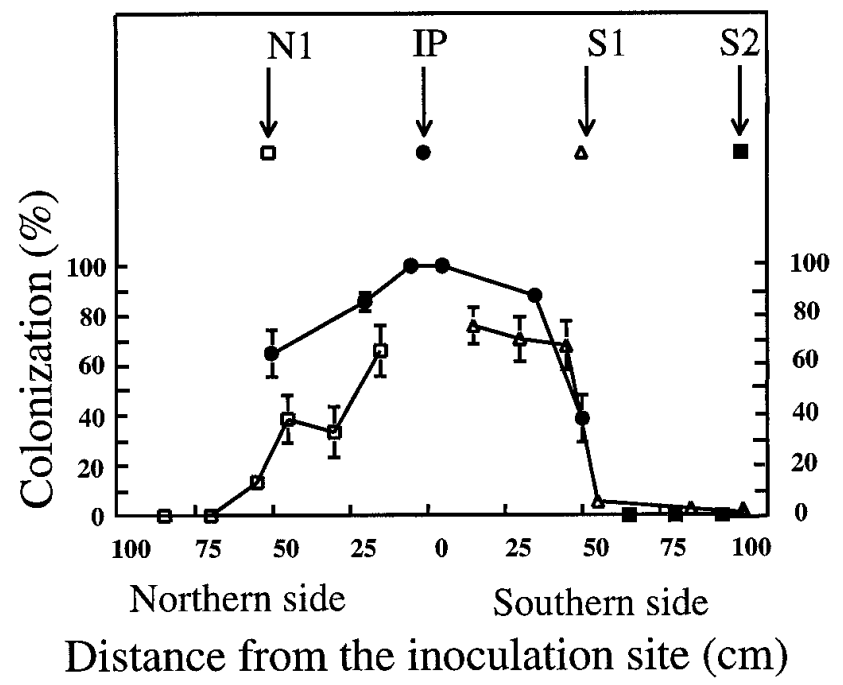

Fig. 8. Spatial pattern of colonization of tomato root segments by a nit mutant of Fusarium oxysporum f. sp. radicis-lycopersici at various distances from the site of inoculation. Arrows indicate the location (in space) of the inoculated and adjacent plants. $\mathrm{IP}=$ the inoculated focus plant, $\mathrm{N} 1=$ first adjacent plant on the northern side of the focus plant, and S1 and S2 = first and second adjacent plants on the southern side of the focus plant, respectively. Bars represent standard error. 


\section{DISCUSSION}

Although soilborne pathogens are generally considered monocyclic, the possibility that a plant infected by a soilborne pathogen would serve as a source of inoculum to adjacent plants has been suggested by several authors $(2,8,14,15,21,23,29-31)$. Recent studies have shown that zoosporic soilborne pathogens such as $P$. capsici and Pythium spp. are polycyclic and are able to spread and infect healthy plants in the field and in the greenhouse during the same growing season $(2,11,12,22,27,31)$. In contrast, polycyclic behavior in nonzoosporic soilborne pathogens is less common $(8,14$, 29,30 ). This study demonstrates that $F$. oxysporum f. sp. radicislycopersici spreads from an infected to neighboring plants within a single growing season via root-to-root dissemination. This conclusion is based on biological studies including the use of tagged inoculum, statistical analyses of data collected from a naturally infested field, and studies conducted in a greenhouse simulation system. Consequently, it is suggested that $F$. oxysporum f. sp. radicis-lycopersici is a polycyclic pathogen in nature. Moreover, progression curves of the disease induced by this pathogen followed a logistic pattern (Fig. 1), further indicating that diseased plants became sources of infection.

Disease distribution in the field during the growing season exhibited a similar pattern in both 1996 and 1997 (Fig. 2). At early stages of the epidemic, a random pattern of diseased plants was observed. Later, clusters of diseased plants were formed and expanded mainly within rows. Toward the end of the epidemic, when most of the plants were already diseased, a random distribution of healthy plants was again observed (Fig. 2). This pattern was confirmed and quantified by the geostatistic analysis that characterized the degree of spatial dependency and the range of pathogen dissemination. All semivariograms showed spatial dependency only in the middle of the season (Fig. 3). In most cases, the range calculated by the semivariograms in the exponential stage of the epidemic was between 1.1 and $4.4 \mathrm{~m}$ (Table 1), corresponding with the data observed in the biological part of the study (Table 2). Geostatistic analyses of epidemics of $P$. capsici in bell pepper fields and downy mildew in cabbage (an airborne disease) reveal similar trends $(22,32)$. In those studies, semivariograms at early stages of the epidemic indicated spatial independence between diseased foci and neighboring areas. As time passed and disease incidence increased, spatial dependence was observed. Spatial dependence of $P$. capsici was highest within rows, and the range reached $15 \mathrm{~m}$. Spread of $P$. capsici in surface water was the primary dispersal mechanism; therefore, disease spread between rows occurred and was also spatially dependent.

Hadar et al. (13) suggested that the nit mutant can be a useful tool for ecological investigations. Indeed, this approach was useful for studying the spread of $F$. oxysporum $\mathrm{f}$. sp. radicis-lycopersici under natural field conditions. This approach has also been used successfully by Takehara et al. (33). The symptoms incited by the mutant, disease progression (Fig. 4), and the pattern of the semivariograms (Fig. 5) were similar to those incited by the indigenous pathogen in this field (Figs. 2 and 3, respectively). The nit mutant pathogen subsequently spread to adjacent plants to a distance of up to four plants $(2 \mathrm{~m})$ on each side of the nit mutantinoculated plant (Table 2). Following the appearance of the first diseased plants (about 90 days after planting), disease continued to spread until the end of the season (Fig. 4). Therefore, when the disease appears earlier, or when the season is extended (e.g., in greenhouses), the pathogen may spread to larger distances within a single growing season. The pattern of root colonization by the nit mutant pathogen showed a decreasing gradient from the site of inoculation to either sides (Fig. 7). This pattern, and the consecutive spread of the disease from one plant to the next, further suggest that $F$. oxysporum f. sp. radicis-lycopersici spreads from root to root. This spread of soilborne pathogens from plant to plant has been demonstrated with the soilborne bacteria Pseudomonas solanacarum in tomato, tobacco, and banana plants (21) and Phytomonas solanacearum in tomato (35) and by soilborne fungi Verticillium albo-atrum in potato $(15,23)$, Pythium spp. in cucumber (31), $P$. capsici in bell pepper $(22,27)$, Sclerotinia sclerotiorum in sunflower (14), Sclerotium cepivorum in onion (29), Sclerotium rolfsii in carrot (30), and Rhizoctonia solani in potato (8). Two mechanisms may be involved in pathogen spread from one plant to another: mycelial growth in the soil toward the root and growth of the pathogen and its spread from root to root. In the absence of roots, F. oxysporum f. sp. radicis-lycopersici movement in the soil was less than $2 \mathrm{~cm}$ after 90 days, as was also found for $F$. oxysporum in oil palm (24). In our study, even after 150 days, the pathogen did not cross the $2.5-\mathrm{cm}$ soil layer in the barrier (Table 3 ), further indicating negligible self-movement of the pathogen or its growth in the soil. It is concluded that roots are essential for the pathogen's movement in the soil. The roots can be regarded as tubes filled with a highly selective and rich habitat where the colonizing pathogen is protected from the activity of antagonistic microorganisms. Therefore, roots are an ideal medium for pathogen growth and an efficient route for its dispersal. Indeed, the rate of pathogen spread via plant roots is equal to, or faster than, its movement in detached roots or culture medium. The intermingling roots appear to facilitate this process. This may explain the rapid progress of the pathogen in the field, which ranged from 1.0 to $3.1 \mathrm{~cm}$ per day (Fig. 6).

Another potential means of pathogen dispersal in space (which was not studied) is via airborne conidia formed on the stems. Conidia on stems are produced by $F$. oxysporum f. sp. radicis-lycopersici (17), F. oxysporum f. sp. basilici (10), F. oxysporum f. sp. lycopersici (19), and other pathogenic forms of $F$. oxysporum (19). If such conidia are capable of infecting plants and causing a disease in the same growing season, the dissemination capacity of the pathogens would be further enhanced.

The polycyclic nature of $F$. oxysporum f. sp. radicis-lycopersici has potential implications for the management of the disease it induces. Each infected plant has the capacity to cause disease in at least four plants to either side of it. Thus, even an initial low disease intensity may result, in due time, in a severe epidemic. Indeed, in the Arava region in Israel, by the end of the season, disease incidence of crown and root rot in tomato plants is commonly high, even in methyl bromide-fumigated soil. Rouging of the diseased plants to prevent dissemination to neighboring plants is a potential

TABLE 3. Infection of tomato plants by a nit mutant of Fusarium oxysporum $\mathrm{f}$. sp. radicis-lycopersici in containers in a simulation system, with or without a barrier ${ }^{\mathrm{a}}$

\begin{tabular}{|c|c|c|c|c|c|c|c|}
\hline \multirow[b]{2}{*}{ Treatment } & \multirow[b]{2}{*}{ Experiment } & \multicolumn{3}{|c|}{ Focus plant $^{\mathrm{b}}$} & \multicolumn{3}{|c|}{ Adjacent plant } \\
\hline & & No. of plants & No. of infected plants & Colonization $(\%)$ & No. of plants & No. of infected plants & Colonization (\%) \\
\hline \multirow[t]{2}{*}{ No barrier } & 1 & 5 & 4 & $25.0 \pm 5.4$ & 5 & 3 & $12.0 \pm 5.6$ \\
\hline & 2 & 6 & 6 & $73.3 \pm 12.5$ & 6 & 5 & $24.0 \pm 9.9$ \\
\hline \multirow[t]{2}{*}{ With barrier } & 1 & 4 & 4 & $55.0 \pm 8.7$ & 4 & 1 & 0.4 \\
\hline & 2 & 5 & 5 & $44.0 \pm 17.4$ & 5 & 0 & 0.0 \\
\hline \multirow[t]{2}{*}{ Noninoculated } & 1 & 1 & 0 & $\ldots$ & $\ldots$ & $\ldots$ & $\ldots$ \\
\hline & 2 & 4 & 0 & $\ldots$ & $\ldots$ & $\ldots$ & $\ldots$ \\
\hline
\end{tabular}

a Two plants were planted $40 \mathrm{~cm}$ apart in 60 -cm-long containers, with or without separation by wooden barrier, with nylon netting.

b Plants artificially inoculated with the nit mutant. 
solution. However, rouging of diseased potato and tomato plants increased the incidence of $V$. albo-atrum $(23,28)$, apparently due to the release of propagules as well as nutrients from the crushed roots. Hence, this practice needs to be further studied. The features of this pathogen and of others that produce aerial conidia call for the development of a holistic, integrated approach to disease management, an approach that will provide protection for the plants before, during, and after planting.

\section{ACKNOWLEDGMENTS}

We thank D. Chellmi, U. Kitron, and H. Voet for their help with the statistics; S. Erez, S. Lourie, and S. Ben-David for their technical assistance; A. Gamliel for valuable suggestions; A. Maduel for technical help in the field during the growing seasons; and T. Katan for providing the nit mutants and for helpful suggestions.

\section{LITERATURE CITED}

1. Bowers, H. H., Sonoda, R. M., and Mitchell, D. J. 1990. Path coefficient analysis of the effect of rainfall variables on the epidemiology of Phytophthora capsici. Phytopathology 80:1439-1446.

2. Bruehl, G. W. 1987. Soilborne Plant Pathogens. Macmillan Publishing Company, New York.

3. Cafe-Filho, A. C., and Duniway, J. M. 1995. Dispersal of Phytophthora capsici and P. parasitica in furrow-irrigated rows of bell pepper, tomato and squash. Plant Pathol. 44:1025-1032.

4. Campbell, C. L. 1986. Interpretation and uses of disease progress curves for root diseases. Pages 38-54 in: Population Dynamics and Management. K. J. Leonard and W. E. Fry, eds. Macmillan Publishing Company, New York.

5. Campbell, C. L., and Powell, N. T. 1980. Progression of diseases induced by soil-borne pathogens: Tobacco black shank. Prot. Ecol. 2:177-182.

6. Chellemi, D. O., Rohrbach, K. G., Yost, R. S., and Sonoda, R. M. 1988. Analysis of the spatial pattern of plant pathogens and diseased plants using geostatistics. Phytopathology 78:221-226.

7. Dandurand, L. M., Knudsen, G. R., and Schotzko, D. J. 1995. Quantification of Pythium ultimum var. sporangiiferum zoospores encystment patterns using geostatistics. Phytopathology 85:186-190.

8. Firman, D. M., and Allen, E. J. 1995. Effects of seed size, planting density and planting pattern on the severity of silver scurf (Helminthosporium solani) and black scurf (Rhizoctonia solani) diseases of potatoes. Ann. Appl. Biol. 127:73-85.

9. Fry, W. E. 1982. Principles of Plant Disease Management. Academic Press, Inc., New York.

10. Gamliel, A., Katan, T., Yunis, H., and Katan, J. 1996. Fusarium wilt and crown rot of sweet basil: Involvement of soilborne and airborne inoculum. Phytopathology 86:56-62.

11. Garrett, S. D. 1956. Biology of Root-Infecting Fungi. Cambridge University Press, London.

12. Gilligan, C. A. Temporal aspects of the development of root disease epidemics. Pages 148-194 in: Epidemiology and Management of Root Diseases. C. L. Campbell and D. M. Benson, eds. Springer-Verlag, Berlin.

13. Hadar, E., Katan, J., and Katan, T. 1989. The use of nitrate-nonutilizing mutants and a selective medium for studies of pathogenic strains of $\mathrm{Fu}$ sarium oxysporum. Plant Dis. 73:800-803.
14. Huang, H. C., and Hoes, J. A. 1980. Importance of plant spacing and sclerotial position to development of Sclerotinia wilt in sunflower. Plant Dis. 64:81-84.

15. Isaac, I. 1953. The spread of diseases caused by species of Verticillium. Appl. Biol. 40:630-638.

16. Isaaks, E. H., and Srivastava, R. M. 1989. Applied Geostatistics. Oxford University Press, New York.

17. Jarvis, W. R. 1988. Fusarium crown and root rot of tomatoes. Phytoprotection 69:49-64.

18. Journel, A. G., and Huijbregts, C. J. 1978. Mining Geostatistics. Academic Press, New York.

19. Katan T., Shlevin, E., and Katan, J. 1997. Sporulation of Fusarium oxysporum f. sp. lycopersici on stem surface of tomato plants and aerial dissemination of inoculum. Phytopathology 87:712-719.

20. Katan, T., Zamir, D., Sarfatti, M., and Katan, J. 1991. Vegetative compatibility groups and subgroups in Fusarium oxysporum f. sp. radicis-lycopersici. Phytopathology 81:255-262.

21. Kelman, A., and Sequeira, L. 1965. Root-to-root spread of Pseudomonas solanacearum. Phytopathology 55:304-309.

22. Larkin, R. P., Gumpertz, M. L., and Ristaino, J. B. 1995. Geostatistical analysis of Phytophthora epidemic development in commercial bell pepper fields. Phytopathology 85:191-203.

23. McKay, M. B. 1926. Further studies of potato wilt caused by Verticillium albo-atrum. Agric. Res. 32:437-470.

24. Park, D. 1959. Some aspects of the biology of Fusarium oxysporum Schl. in soil. Ann. Bot. 23:35-49.

25. Pfender, W. F. 1982. Monocyclic and polycyclic root diseases: Distinguishing between the nature of the disease cycle and the shape of the disease progress curve. Phytopathology 72:31-32.

26. Rekah, Y., Shtienberg, D., and Katan, J. 1997. Dissemination in space and survival in time of Fusarium oxysporum f. sp. radicis-lycopersici. (Abstr.) Phytoparasitica 25:249.

27. Ristaino, J. B. 1991. Influence of rainfall, drip irrigation, and inoculum density on the development of Phytophthora root and crown rot epidemics and yield in bell pepper. Phytopathology 81:922-929.

28. Roberts, F. M. 1943. Factors influencing infection of the tomato by Verticillium albo-atrum. Ann. Appl. Biol. 30:327-331.

29. Scott, M. R. 1956. Studies of the biology of Sclerotium cepivorum. II. The spread of white rot from plant to plant. Ann. Appl. Biol. 44:584-589.

30. Smith, V. L., Campbell, C. L., Jenkins, S. F., and Benson, D. M. 1988. Effects of host density and number of disease loci on epidemics of southern blight of processing carrot. Phytopathology 78:595-600.

31. Stanghellini, M. E., Rasmussen, S. L., Kim, D. H., and Rorabaugh, P. A 1996. Efficacy of nonionic surfactants in the control of zoospores spread of Pythium aphanidermatum in a recirculating hydroponic system. Plant Dis. 80:422-428.

32. Stein, A., Kocks, C. G., Zadoks, J. C., Frinkin, H. D., Ruissen, M. A., and Myers, D. E. 1994. A geostatistical analysis of the spatio-temporal development of downy mildew epidemics in cabbage. Phytopathology 84:1227-1239.

33. Takehara, T., and Kuniyasu, K. 1995. Use of nitrate nonutilizing mutants in ecological studies of Fusarium diseases. III. Growth, benomyl sensitivity, pathogenicity, and stability of nit mutants of Fusarium oxysporum compared to wild-type strains. Ann. Phytopathol. Soc. Jpn. 61:541-548.

34. Van der Plank, J. E. 1963. Plant Diseases: Epidemics and Control. Academic Press, London.

35. Vaughan, E. K. 1944. Bacterial wilt of tomato caused by Phytomonas solanacearum. Phytopathology 34:443-458. 